\title{
Health and Social Assessment of Internally Displaced People (IDP) in Nigeria
}

\author{
İlker Etikan* and Ogunjesa Babatope \\ Department of Biostatistics, Near East University, Cyprus
}

*Corresponding author: İlker Etikan, Near East University, Faculty of Medicine, Department of Biostatistics, Nicosia-TRNC, Cyprus.
Received Date: June 04, 2019

Published Date: June 10, 2019

\begin{abstract}
Introduction: The problems of Internally Displaced Peoples (IDPs) have continued to generate global debate in recent times owing to its negative implication on society organization structure and public health. The major drivers of forced human displacement have been attributed to global climate change and armed human conflicts and the developing countries are worst hit with very dearth aftermath effect of this unplanned human displacement. Nigeria as a pivotal country in the sub-Saharan region of Africa and the entire Africa continent at large have not been spared from this sordid occurrence.

Method: The article considers review of some published reports by several humanitarian organizations such as WHO, UN, IDMC and other published articles.

Result: The increasing armed conflict in the North-East Region of Nigeria is geometrically increasing the numbers of IDPs in the country. Many families are at risks of poverty, hunger and disease. And also, the dearth impact of this forced displacement has continued to lower the Nigeria rankings in global health and socio-economic indicators.
\end{abstract}

Keywords: Internally displaced people; Diseases; Boko-haram; Forced displacement

\section{Introduction}

Globally, the rule of law for human rights posits the right of everyone to benefit from adequate housing, social security and a good standard of living. According to the United Nations, human rights on adequate ousing factsheet $21 /$ rev20, the right to adequate housing provision include: "Protection against forced evictions and the arbitrary destruction and demolition of one's home; The right to be free from arbitrary interference with one's home, privacy and family; and The right to choose one's residence, to determine where to live and to freedom of movement." Pp. 3 (UN-Habitat (n.d)). However, despite the various international and national human rights law that seeks to ensure a healthy and balanced environmental friendly atmosphere for mankind, the world today still grapple with many avoidable challenges and conflicts which are often tied to human direct/indirect actions that threaten human habitation. These actions have resulted in the rising figures of Internally displaced peoples (IDPs) globally. In the latest development, from the South America continent to the Africa continent and the South Asia region, the news about forced human migration is evident. Notable in recent times is the news of human caravans heading to the United States (US) fleeing economic hardship from Southern America, the Rohingya crisis in Myanmar to the migrants crossing the Mediterranean from Africa.

Internally displaced people are individuals that are forcefully ejected from their place of abode. The internal displacement monitoring center (IDMC) stated that the displacement of people from their place of abode has become a recurrent issue with accompanied social, health and economic burden globally (IDMC,2018). There are two broad categories of factors attributable to forced human evictions namely; conflicts and natural disasters. In regards to conflicts, this could be a religious crisis, communal violence, political violence, criminal violence, insurgency and other forms of armed conflicts while disasters could be as a result of wildfires, typhoons, cyclones, earthquakes, volcano eruptions, floods, landslides, drought among all other factors [1,2].

The eminent threat associated with global climate change and its impact on the human settlement has continued to generate 
concern across the globe. The rising sea level has resulted in flooding that has washed away many human settlements especially in the South- East Asia of with many communities still at the risk of this disasters. Aside from flooding, another causal problem of human displacement attributable to climate change is famine [3]. Drop in falling rains affects livestock and farming activities which are needed for human sustenance. The survivability of any community depends on food and water. Once this provision chain is cut off, the basic instinct in man is to seek locations where such need can be met. Relative to this, humans are forced out of their abode unwillingly.

According to the 2017 year-end report of the United Nations Refugee Agency (UNHCR), the prevalence of forced displaced individuals was 68.5 million people worldwide as a result of a number of factors such as insurgency, economic artist, natural disasters and so on. This entails that about 44,400 people daily are been displaced. The new incidence of forced displayed individuals was 16.2 million people inclusive of 4.4 newly displaced refugees and asylum seekers and 11.8 million people displaced within their home countries. About $85 \%$ of the burden of forced displaced individuals occurred among the developing regions of the world and $52 \%$ of the prevalence are children below 18 years old. Five countries of the world contributed about two-thirds (68\%) of the global forced displaced individuals. These countries are Syrian Arab Republic (6.3 million), Afghanistan (2.6 million), South Sudan (2.4 million), Myanmar (1.2 million) and Somalia with 986,400 people [4].

The increasing trend of forcibly displaced people was also evident in the number of an asylum seeker. The UNHCR stated that 1.7 million asylum applications were filed for the year 2017. The
United States of America received the world's largest record of asylum application of 331,700 claims followed by Germany which received about 198,300 claims. Italy received 126,500 of such claims and Turkey received 126,100 claims application. In the global place, Turkey remained the largest host to refugees from troubled nations with about 3.5 million individuals. This was followed by Pakistan and Uganda with 1.4 million people respectively. The resultants effects of the severe deprivation, hardship, and discrimination as a result of this forced displacement have continued to resonate across the globe [4].

\section{IDPs in Africa}

In the Africa continent, the sub-Saharan region is the worst hit in terms of internally displaced people. The continent continues to record an increasing number of Internally displaced people despite the efforts to have this occurrence mitigated [5]. According to the internal displacement monitoring center report, over 3.9 million new displaced people occurred in the year 2016 ending. This group of people included both old and young that are physically and psychologically deprived of their human rights and made to cruel deprivations and many other forms of atrocities and abuse [6].

Though the sub-Saharan region only accounts for about $14 \%$ of the global population, about half of the world forced displacement occurred in this region. In the year 2017, 5.5 million people were displaced as a result of the conflict. As a result of conflicts and disasters, about 2,193,000 people were displaced in the Democratic Republic of Congo (DRC), 1,287,000 people were displaced in Somalia, 1,159,000 individuals were displayed in South-Sudan and about 542,000 people were displayed in Central Republic of Africa (CAR) (Figure 1).

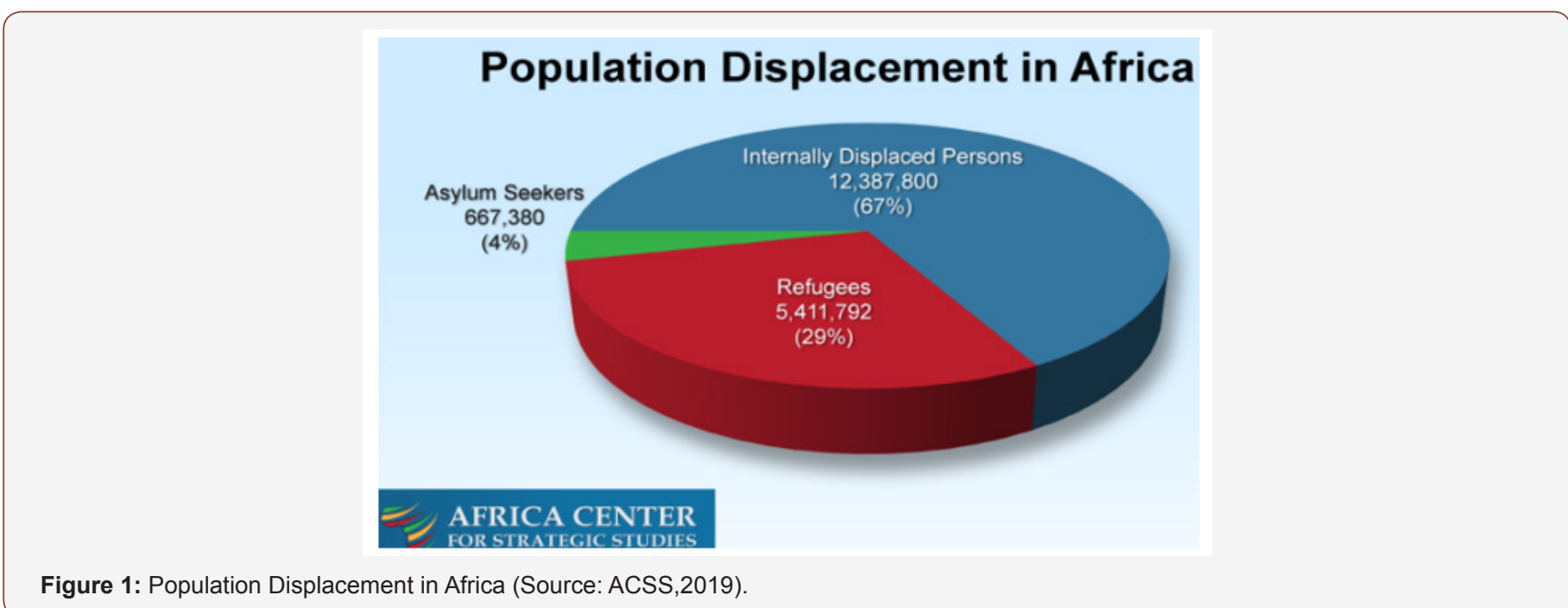

\section{The state of IDPs in Nigeria}

Nigeria is a prominent nation in the Africa continent as well as in the sub-Sahara region of Africa. The country is located in the West Africa region of the Africa continent and reputed as the most populous black nation in the world with a population of 198 million people. The country occupies a total area of about $923768 \mathrm{~km} 2$ and a population density of $215.27 \mathrm{p} / \mathrm{km} 2$. Nigeria is politically divided into 6 distinct regions namely: South-west; South-East; SouthSouth; North East; North -West and North Central. There are 36 states in the country including the Federal capital territory (Abuja) which also doubles as the Nation's Capital. The language and ethnic diversities in the country are enormous. The country has more 400 tribes and languages. However, the three major ethnic groups are the Yoruba's (popularly found in the south-west region); The Igbo's 
(commonly domicile in the South-East region) and the Hausa's/ Fulani's (popularly found in the Northern region of the country).

Nigeria just like some of her counterparts in the troubled subSahara Africa is not free from the woes of internal displacement [7]. The continual armed crises, as well as the occurrence of natural disasters, have resulted in a high trend of IDPs in the country. According to the IDMC, Nigeria recorded a total number of $1,707,000$ IDPs in the year 2017. The incidence of IDPs for the year 2017 due to conflicts and violence was 279,000 people and 122,000 people occurred as a result of disasters [8]). The highest account of displaced people in the country occurred in Borno, Adamawa and Yola states which are all found in the North-East part of the nation. The North East region accounts for about $94 \%$ of the total displaced people in the country. Apart from the North East region of the country, the middle belt of the nation prominently Benue State also have a share of the

IDP as a result of armed conflicts. In the coastal part, the ocean side communities such as Otodo-Gbame community in Lagos State were forcibly evicted from their place of abode without requisite resettlement plan. This Otodo-Gbame forced eviction resulted into 30,000 IDP [9] (Figure 2).

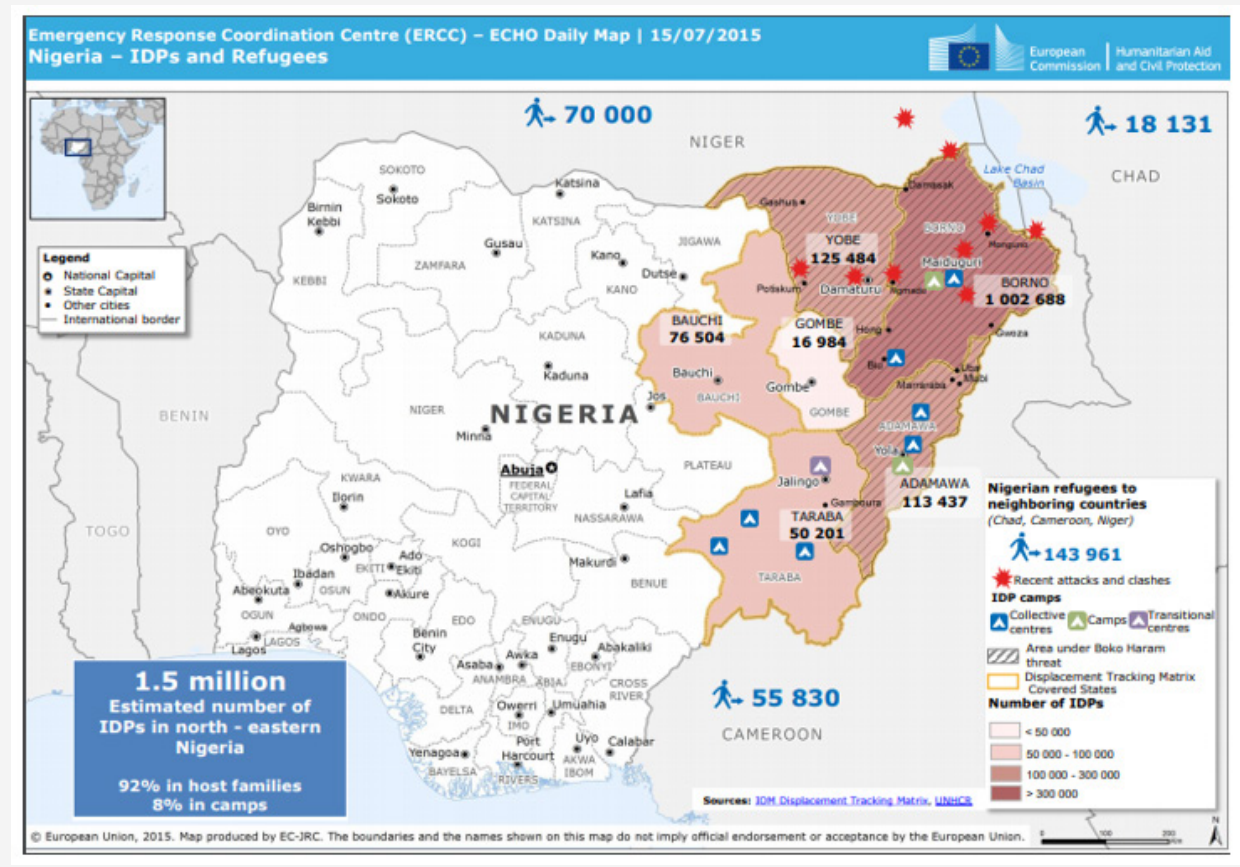

Figure 2: Map of Internal Displacement in Nigeria, (Source: Relief Web,2015).

There are several risk factors that are responsible for the displacement records in the country with social, environmental, economic and political undertones. Despite this multi-linked factor, there are well-pronounced drivers are prominently tied to armed conflicts and insurgency activities. This was made worse by the activities of the dreaded "Boko-Haram" Jihadist group. BokoHaram; a once political movement group metamorphosed into a terror heralding group leaving hundreds and thousands dead and millions displaced since its violence campaign started in the year 2014. The havoc rendered by this group which continues to be virulent has turned the entire North-East region of the country a high-security risk zone for property and lives. This results into an upsurge of mass movement of people from this region to relatively safe places with many of them housed in various IDPs camps across the nation. These resettlement processes have inadvertently heightened communal tensions with some host communities resulting in another chain crisis and restiveness. The recent Fulani herdsmen onslaught in the Northern and the middle belt region of the country have further contributed to the high numbers of IDPs in the country.
The Nigeria Government is a signatory to the Kampala Convention of 2009 of the African Union Convention for the Protection of Internally Displaced Persons aimed at providing guidance on Internal Displacement as an international standardsetting guideline on IDPs to handle this crisis [10]. In a broad term, the Kampala convention's goal seeks to "promote and strengthen regional and national measures to prevent or mitigate, prohibit and eliminate root causes of internal displacement as well as provide for durable solutions" (as cited in Kampala Convention [11]). The country also set up a national disaster and conflict agency called the National Emergency Management Agency (NEMA) to help coordinate and manage disasters occurrence in the nation and also in conjunction with other state-controlled agencies. The Organization is also responsible to help manage the various IDP camps with the support of both local and international nongovernmental agencies (NGOs) in the country.

\section{Effects of Forced Displacement in Nigeria}

The growing numbers of IDP in various IDP camps and other host communities have remained a major national burden in the country. Socio-Economic Effect: The displacement as a result of 
disasters or armed conflicts do lead into dysfunctional economic systems of the areas left behind by fleeing refugees [12]. The IDP lose their homes, place of works, businesses, as well as other forms of investments. Public facilities are destroyed and valuables of IDP are destroyed and their household income cutoff. This displacement not only affects the IDP earnings but also paralyze every economic structure of trade and commerce of the affected vicinity with resonating effects in other regions due to the disruption of the supply chain. External business investors such as financial institutions and telecommunication companies in affected areas also stand the risk of poor financial performance, job cuts and other forms of operational crisis.

Over-Crowded IDP Camps and Diseases Spread: In Nigeria, most IDPs are camped. The common sight in many of these camps is over crowdedness. This problem of overcrowding often resulted in overstretched usage of the limited available facilities and infrastructural supports present in these camps. The constant influx of people into these already overcrowded camps makes their condition more appalling. read: Aside the psychological trauma that characterized IDPs, their poor living conditions in these IDP camps have further aggravated their susceptibility to ill health and other forms of diseases occurrence especially the communicable type of diseases that are quite prone in this part of the world such as malaria, Hiv/Aids, tuberculosis, and cholera. The Doctors Without Borders; a global humanitarian aid agency, reported a deadly cholera outbreak in one of the North-East IDP camps in 2017 with many casualties [13-17].

Poor Environment Maintenance and Water Contamination: A major risk factor for the spread of many infectious diseases is poor environmental management and water pollution. Nigeria as a country is equally known for many environmental hazard's practices such as open defecation and poor household disposals. Nigeria is the foremost country in Africa and the second in the world after India practicing open defecation with about 47 million Nigerian people engaging in this practice (Obinna,2018). The practice of open defecation and other environmental degradation practices are highly prevalent in IDPs camps. The passing of these solid wastes often finds their ways to water sources present in these camps which most of them equally find useful for drinking and other domestic activities. This poor sanitation portrays a high risk to public health of IDPs and serves as a hotbed for ill-health conditions thus endangering their health.

Poverty and Hunger: The Brookings Institute in 2018 made a report based on the World Poverty Clock that Nigeria is the world capital of poverty with about 87 million Nigerians living below $\$ 1.90$ USD. The bane of poverty can be seen across the country as evidenced by the standard of living of the majority in the country. As a result of low household income across the country and poor economic stability, the woes of IDPs are further compounded. Majority of IDPs in camps are only given paltry rations of foods which can barely fulfill the nutritional need of the human body. As a result of hunger, the nutrition intake most especially the children in these camps are very poor resulting in high mortality and morbidity of under-five. The women and the aged which form the largest cohorts of the IDPs are severely affected. The endemic poverty condition of IDPs has a contributory impact on the low ranking of Nigeria in terms of life expectancy, under-five mortality, maternal death among many other health indicators.

Low School Enrollment: Human displacement in Nigeria also has a contributory factor to the poor record of school enrollment of children in schools. About 10.5 million children between the ages of 5 to 14 years are not enrolled in schools and about $61 \%$ of children aged 6-11 years enrolled in primary school education. Most children of IDPs stay out of schools as a result of displacement that their parents or guardian experienced. The destabilized household settings as a result of forced movement of people do hinder the enrollment of children into schools.

Crime and Drug Abuse: In a bid to obtain some sort of mental relief from the psychological effects of forced displacement, many IDPs becomes more susceptible to the use of drugs and other harmful substances such as cocaine, heroin, marijuana and so on. The use of these drugs often drives victims to form gangs which could eventually translate to commit crimes. Also, the spread of deadly diseases such as Hiv/Aids through sharing of needles during drug injections is facilitated.

The effects of IDPs on any society are enormous. Asides the instability woes and loss of lives, it affects the economy and threatens the health of the human population. Therefore, the Nigeria government needs to adequately reckon to the impacts that forced human displacement to exert on the country. The government needs to facilitate a peace process that can curtail the current insurgency activities in the North-East region of the country and the fight between Fulani herdsmen and locals. Existing IDPs camps need to be upgraded and made more habitable for occupants. The government should ensure that aids donated towards the wellbeing of IDPs are well utilized and should prevent any form of diversion as it has been previously recorded in some quarters. The resettlement of IDPs should be taking as a high priority and rebuilding process should hasten in areas that are considered now safe for the return of IDPs. It is urged that the government existing relationship with both national and international non-government organizations (NGOs) should be strengthened especially in the area of health and economic empowerment of IDPs.

\section{Acknowledgement}

None.

\section{Conflict of Interest}

No conflict of interest.

\section{References}

1. Ogenga Otunnu (2002) Population Displacements: Causes and Consequences. Retrieved from https://refuge.journals.yorku.ca/index. php/refuge/article/viewFile/21278/19949.

2. Peterson T, Stott P, Herring S (2012) Explaining Extreme Events of 2011 from a Climate Perspective, Bulletin of the American Meteorological Society: 1041-1067. 
3. Shen J (2013) 'Increasing Internal Migration in China from 1985 to 2005 : Institutional Versus Economic Drivers', Habitat International 39: 1-7.

4. United Nation Refugee Agency [UNHCR] (2017) Global Trend in Forced Displacement in 2017. Retrieved from https://www.unhcr.org/ globaltrends2017/ on29th of Dec 2018.

5. Kevin M Dejesus (2018) Forced migration and displacement in Africa: contexts, causes and consequences, African Geographical Review 37(2): 79-82.

6. Norwegian Refugee Council/Internal Displacement Monitoring Centre (NRC/IDMC) (2018) Global Report on Internal Displacement - Sub-Saharan Africa. Retrieved from: https://www.refworld.org/ docid/5b28b7211.html.

7. Heerten L, Moses AD (2017) Postcolonial Conflict and the Question of Genocide. Routledge.

8. Internal Displacement Monitoring Centre [IDMC](2017b) Nigeria profile. Retrieved from http://www.internal-displacement.org/ countries/nigeria.

9. Mazi Emmanuel (2017) Otodo Gbame Demolition: How Victims of Lagos's Forced Demolitions Survive - One Day at a Time. Retrieved from https://thisisafrica.me/otodo-gbame-demolition-how-victims-oflagoss-forced-demolitions-survive-one-day-at-a-time/.

10. Ekpa S, Dahlan NHM (2016) Legal Issues and Prospects in the Protection and Assistance of Internally Displaced Persons (IDPs) in Nigeria. Journal of Law, Policy, and Globalization 49: 108-116.
11. African Union (2009) Convention de l'Union Africaine sur la protection et l'assistance aux personnes déplacées en Afrique ("Convention de Kampala"), 22 October 2009, available at: https://www.refworld.org/ docid/4ae825fb2.html.

12. Bhagwan KS (2013) Conflict-Driven Internally Persons in Manipur: Legal and Human Security Framework. Master's Dissertation, Sikkim University, Gangtok.

13. Voice of America [VOA] (2017) Cholera Outbreak Threatens More Than 1M People in Nigeria Refugee Camps. Retrieved from https://www. voanews.com/a/cholera-outbreak-threatens-more-than-one-millionpeople-in-nigeria-refugee-camps-/4019759.html.

14. Africa centre for Strategies Studies [ACSS] (2019) Population Displacement in Africa: Top 10 Countries of Origin. Retrieved from https://africacenter.org/spotlight/population-displacement-africa/.

15. Internal Displacement Monitoring Centre (2018) The ripple effect: Economic impacts of internal displacement. Retrieved from http://www. internal-displacement.org/sites/default/files/inline-files/20180608idmc-economic-impacts-intro_0.pdf.

16. Relief Web (2015) Nigeria - IDPs and Refugees - ECHO Daily Map. Retrieved from https://reliefweb.int/map/nigeria/nigeria-idps-andrefugees-echo-daily-map-15072015.

17. UN-Habitat (2018) The Right to Adequate Housing. Fact Sheet No. 21/Rev.1. Retrieved from https://www.ohchr.org/Documents/ Publications/FS21_rev_1_Housing_en.pdf on 29th of December,2018. 